\title{
LIVROS PARA CRIANÇAS ILUSTRADOS E PREMIADOS: UMA EXPERIÊNCIA DE LEITURA EM BIBLIOTECA ESCOLAR
}

\author{
Hércules Tolêdo Corrêa (UFMG) \\ Daniela de Carvalho Pena Gonçalves (UFOP)
}

Resumo: $O$ presente estudo visa refletir sobre elementos textuais e gráficos presentes em três livros de literatura infantil premiados pela Fundação Nacional do Livro Infantil e Juvenil (FNLIJ), na categoria Criança, no ano de 2018 (produção 2017). Pretende-se, como foco principal, analisar a apropriação estética dessas obras literárias por um grupo de crianças inseridas em turmas dos anos iniciais do ensino fundamental de uma escola pública municipal do interior de Minas Gerais. O aporte teórico pauta-se nos estudos da imagem em livros infantis (HUNT, 2010; LINDEN, 2011 e RAMOS, 2013) e do letramento literário (COSSON e PAULINO, 2009; CORRÊA, 2016 e COSSON, 2017), dentre outros. Para o trabalho de campo, utilizamos como base a dinâmica do Círculo de Leitura (COSSON, 2017) com vistas a observar e dialogar com os sujeitos sobre a produção de sentidos em práticas de leitura mediada. As análises dos dados evidenciaram a relevância da articulação criativa e eficiente entre as linguagens escrita e visual, que ampliam as possibilidades de leitura e fomentam o interesse do leitor. A investigação também revela que as crianças foram desafiadas, transitaram pelas camadas de signos dispostas nas páginas, compartilharam sentidos, estabeleceram estratégias de leitura frente ao texto e apresentaram em suas falas detalhes relevantes que se abrem para outras possibilidades de leitura da produção para elas destinadas.

Palavras-chave: Literatura infantil; Livro ilustrado; Letramento literário.

Abstract: The present study aims to reflect on textual and graphical elements present in three children's literature books awarded by the Brazil National Foundation of Children and Youth Book (FNLIJ), in the category of Children, in the year 2018 (2017 production). The main focus is to analyze the aesthetic appropriation of these literary works by a group of children in the early years of elementary school in a public school 
located in an inland city of Minas Gerais state, Brazil. The theoretical framework is based on image studies in children's books (HUNT, 2010; LINDEN, 2011 and RAMOS, 2013), and on literary literacy (COSSON and PAULINO, 2009; CORRÊA, 2016 and COSSON, 2017), among others. For the fieldwork, we use as reference the dynamics of the Reading Circle (COSSON, 2017) for observing and dialoguing with the research participants about sense production in mediated reading practices. The data analysis showed the relevance of efficient and creative connections between written and visual languages that extend the possibilities of reading and promote reader interest. The investigation also reveals that the children have been challenged, could transit for the sign layers arranged on the pages, shared senses, determined reading strategies to understand the text and showed in their speech relevant details that open up to other reading possibilities of the production to them addressed.

Keywords: Children's literature; Illustrated book; Literary literacy.

Um escritor de livro ilustrado tem que saber que aquilo que ele está escrevendo é apenas um ingrediente da obra, não corresponde ao todo. $O$ autor do texto não é necessariamente o autor do livro. A autoria da obra é muitas vezes dividida em três - o designer, o ilustrador e o escritor.

Odilon Moraes

\section{CONSIDERAÇÕES INICIAIS}

Com relação ao livro destinado às crianças, cada vez mais escritores, ilustradores e designers gráficos (bem como editores e demais profissionais envolvidos na indústria do impresso) procuram garantir um conjunto harmônico, envolvendo um processo criativo de uma camada de signos que demanda do leitor abordagens diversas para a produção de sentido. Podemos, inclusive, falar em uma "autoria coletiva", com protagonistas e coadjuvantes, todos unidos 
para a produção de uma obra que preza pela qualidade. Essas obras requerem um olhar atento e conhecimentos para as relações cada vez mais criativas que compõem o projeto gráfico-editorial de uma obra: a mescla entre a linguagem verbal e a linguagem visual presentes nos livros de literatura infantil em prol da fruição estética por parte do leitor. Tais características demonstram as especificidades presentes no livro ilustrado que é considerado "não apenas um objeto cujas mensagens contribuem para produção de sentido, mas um conjunto coerente de interações entre textos, imagens e suportes" (LINDEN, 2011, p.9). Nessa perspectiva, esse objeto artístico com as diversas linguagens integradas contribui para instigar diferentes perspectivas de leitura e demanda do leitor em formação exigências para uma leitura crítica para significação da obra.

Vale destacar que este artigo foi produzido no âmbito de um projeto maior intitulado LITERATURA E VISUALIDADE: a importância do projeto gráfico em livros para crianças na contemporaneidade, desenvolvida pelo Grupo MULTDIC Multiletramentos e usos das TDIC na Educação. Partimos de uma reflexão sobre as obras premiadas na categoria Criança pela Fundação Nacional do Livro Infantil e Juvenil (FNLIJ) e em seguida procuramos identificar e analisar a recepção 
estética dessas obras no âmbito escolar por alunos dos anos iniciais do ensino fundamental público de uma cidade do interior de Minas Gerais.

Procuramos responder as seguintes questões: $O$ que caracteriza uma obra de qualidade destinada às crianças, na atualidade? O que faz de uma obra merecedora de um prêmio literário, como o conferido anualmente pela Fundação Nacional do Livro Infantil e Juvenil? Como tem sido a recepção dessas obras pelo seu público-alvo, ou seja, as crianças? Que elementos as crianças consideram ao ler um livro ilustrado?

Apresentamos e analisamos, neste artigo, três obras premiadas pela FNLIJ, na categoria Criança, no ano de 2018 (produção 2017): 1) A quatro mãos, da consagrada escritora e ilustradora Marilda Castanha, na categoria Hors-Concours (Editora Companhia das Letrinhas); 2) Rosa, do escritor e ilustrador Odilon Moraes, premiado também como melhor ilustração (Editora Olho de Vidro); e 3) O passeio, escrito por Pablo Lugones e ilustrado por Alexandre Rampazzo (Editora Gato Leitor).

Assim, dividimos este artigo em três partes. Na primeira, tecemos algumas considerações sobre livros ilustrados e letramento literário, a fim de fundamentar teoricamente 
a pesquisa. A segunda parte consiste em uma breve apresentação e análise das obras, na qual mobilizamos conhecimentos e realizamos nossas leituras dos três livros selecionados no sentido de conhecer a produção, os aspectos de sua constituição, para se pensar a mediação de leitura em uma prática desenvolvida em uma biblioteca escolar. Na terceira parte, tratamos da apropriação estética de um grupo de crianças das obras literárias premiadas e a elas destinadas, a partir da referida prática de mediação de leitura literária.

\section{LIVROS ILUSTRADOS E LETRAMENTO LITERÁRIO}

As três obras aqui apresentadas e analisadas podem ser classificadas como livros ilustrados. A partir de suas pesquisas com teóricos e obras para crianças, principalmente produzidas na Europa, Peter Hunt (2010) apresenta uma diferença conceitual entre livro com ilustração e livro-ilustrado. ${ }^{1}$ Para o referido pesquisador, o último é aquele objeto que tem a ilustração como sua parte constitutiva. Enquanto chamamos de livros com ilustração as obras que podem ser editadas independentemente do trabalho do ilustrador. No caso dos livros ilustrados, ainda que a autoria textual e a autoria das imagens seja diferente, autor e ilustrador têm importância

1 Hunt (2010) grafa a expressão com hífen, com o objetivo de estabelecer a diferença de sentido. Como muitas outras publicações trazem a expressão sem hífen, optamos por usá-la da forma mais comum na bibliografia brasileira especializada. 
semelhante no processo de criação e da obra. Ramos (2013, p.84) destaca nesse tipo de produção a interdependência entre palavra e imagem. Segundo ela, a expressão "livro ilustrado" corresponde ao termo inglês picturebook e ao hispânico livro-álbum. Essa produção é caracterizada por ser feita "com uma sequência de imagens de caráter 'essencial'" (RAMOS, 2013, p.85). Encontramos ainda, as expressões livre d'images, em língua francesa, e álbum ilustrado, em Portugal. Acreditamos que o livro ilustrado, por suas características e especificidades, altera o modo de leitura do texto verbal, tornando mais amplas as possibilidades de leitura, noutras palavras, tornando-a mais "enriquecida".

Hunt (2010), no capítulo intitulado "A crítica e o livroilustrado", afirma que há ainda quem desvalorize esse tipo de livro/literatura, por julgar que as metáforas são expressas mais pelos elementos visuais que pelos recursos verbais (modalidade da linguagem privilegiada pela literatura em geral), defendendo a necessidade de uma proposta crítica específica para esta área, pelas características intrínsecas dos livros-ilustrados: exploram relações complexas entre verbal e visual; palavras podem interpretar as imagens ou vice-versa; esses livros cruzam os limites entre os mundos verbal e pré-verbal; as obras desenvolvem a diferença entre 
ler palavras e ler imagens; os livros "não são limitados por sequência linear, mas podem orquestrar o movimento dos olhos", ou seja, lidam com dois argumentos, o visual e o verbal. Pelo exposto, percebe-se um grande potencial semiótico e semântico das obras. Consequentemente, Hunt ressalta o importante papel do ilustrador, uma vez que toda ilustração é uma forma de interpretação. Com o livro ilustrado, adultos e crianças encontram-se em seu ponto de maior proximidade. Desses pressupostos, surgem mais perguntas: $O$ que determina a qualidade de um livro ilustrado? Existe algum modo de lê-lo que nos permita fazer esse juízo de valor? Apesar do destaque ao livro ilustrado, percebemos certa instabilidade quanto ao valor desse tipo de livro e sua relação com a crítica. Hunt reconhece o valor do livro ilustrado definindo-o assim justamente por suas relações complexas com a palavra.

No Brasil, certamente, a relação palavra-imagem é a qualidade maior da literatura infantil nos tempos atuais. Assim, lembramos que a literatura infantil brasileira vem adquirindo desde $O$ final do século $X X$ qualidades significativas e atinge um status altamente complexo, isto é, polifônica, com um emaranhado de códigos que assumem uma coerência enriquecedora. A literatura infantil brasileira vem exigindo leitores altamente competentes. 
Com relação ao livro ilustrado, além de texto verbal e imagem, o projeto gráfico é fundamental na sua concepção: é preciso atentar para o formato, material, relação entre capa e folhas de guardas, tipo e tamanho de fontes utilizadas, enquadramento e encadeamento do texto e das imagens, disposição e localização das mensagens no suporte. Todas essas características fazem muita diferença no resultado final do objeto livro e também na sua leitura, na interação com o leitor. $O$ livro ilustrado é bastante diversificado quanto à sua produção, por não possuir uma diagramação regular identificável, como ocorre com as histórias em quadrinhos, por exemplo. Para Linden as organizações internas do livro ilustrado e as ocupações do suporte "parecem quase infinitas, jogando com o tamanho das mensagens, com seu aspecto formal, com a separação entre elas, com a ocupação da página dupla..." (2011, p.87). A diagramação do livro é pensada a serviço da expressão. A partir desse entendimento, o livro ilustrado afirma e consolida o espaço e o status da imagem. A ilustração é preponderante no livro ilustrado e a ocupação espacial das imagens é superior a do texto escrito, sem contanto, torná-lo secundário. Ilustradores são considerados coautores das obras com essas características já há algum tempo, no mercado editorial, sendo identificados assim em fichas catalográficas, referências e na arrecadação dos direitos autorais. 
Como temos discutido em artigos anteriores, a saber: Letramento literário na escola (CORRÊA, 2016) e Letramento literário dentro e fora da escola: a recepção de $O$ olho de vidro do meu avô, de Bartolomeu Campos de Queirós, e um projeto de leitura literária realizado com alunos do sexto ano do EF (CORRÊA e MAGALHÃES, 2020, no prelo), distinguimos leitura de literatura, leitura literária e letramento literário. Para o senso comum essas duas expressões podem ser entendidas como sinônimas, sem qualquer alteração de sentido. Para os estudiosos da área, no entanto, existe uma diferença de concepção no uso de uma ou outra expressão. Enquanto por leitura de literatura entende-se um ato cognitivo de decifrar o código linguístico de um texto dito literário, podendo ter com isso objetivos diversos, tais como encontrar informações sobre quaisquer conteúdos no texto; aprender sobre determinado assunto ou até mesmo passar o tempo que se tem de ócio, entendemos por leitura literária um tipo específico de leitura que se faz de um texto dito literário, com objetivo de frui-lo esteticamente. Por fruição estética entendemos a experiência de leitura e interação com a obra literária que nos permite apreciá-la cognitiva e emocionalmente, uma forma de interação do leitor com a obra que desperta sensações, sentimentos, emoções. Acreditamos que seja preciso desenvolver mais que o hábito 
de leitura, é preciso desenvolver o gosto pela leitura, dessa maneira, o processo de fruição da obra literária permanecerá com os alunos pela vida afora, sem as imposições típicas do universo escolar.

A partir da concepção de leitura literária associada ao conceito de letramento, que teve ampla repercussão e desenvolvimento nas últimas décadas, nas áreas acadêmica e escolar, surgiu e se desenvolveu o conceito de letramento literário. Ainda no final dos anos 1990 e início do segundo milênio, o grupo de pesquisa em literatura infantil do Centro de Alfabetização, Leitura e Escrita da Faculdade de Educação da Universidade Federal de Minas Gerais passou a denominar-se Grupo de Pesquisa do Letramento Literário - GPELL. Esse grupo foi um dos maiores responsáveis pela difusão da expressão letramento literário no meio acadêmico, principalmente através do evento Jogo do Livro, que tem reunido, a cada biênio, pesquisadores, professores, escritores, editores, bibliotecários e tantos outros profissionais interessados na discussão das relações entre literatura e escola. Portanto, o letramento literário pode ser definido como "processo de apropriação da literatura enquanto construção literária de sentidos" (PAULINO e COSSON, 2009, p.67). 
Além de se configurarem como livros ilustrados, as três obras aqui analisadas apresentam outros pontos em comum, como a temática da relação familiar, mais especificadamente, a relação entre filho ou filha e a figura paterna; e a representação da passagem do tempo nas narrativas por meio de expressões verbais e aspectos visuais, como as cores. Essas características são abordadas na próxima seção.

\section{AS TRÊS OBRAS PREMIADAS PELA FNLIJ NA CATEGORIA CRIANÇA EM 2018 (PRODUÇÃO 2017)}

Apresentamos aqui uma descrição analítica das três obras premiadas, com a intenção de mostrar para o leitor como se articulam texto verbal, imagens e projeto gráfico. O ideal é a descrição acompanhada de imagens dos livros ou, melhor ainda, do próprio livro, o que não é possível neste contexto. Para minimizar um pouco a dificuldade de visualização das obras como um todo, reproduzimos suas capas antes de cada uma das apresentações. 


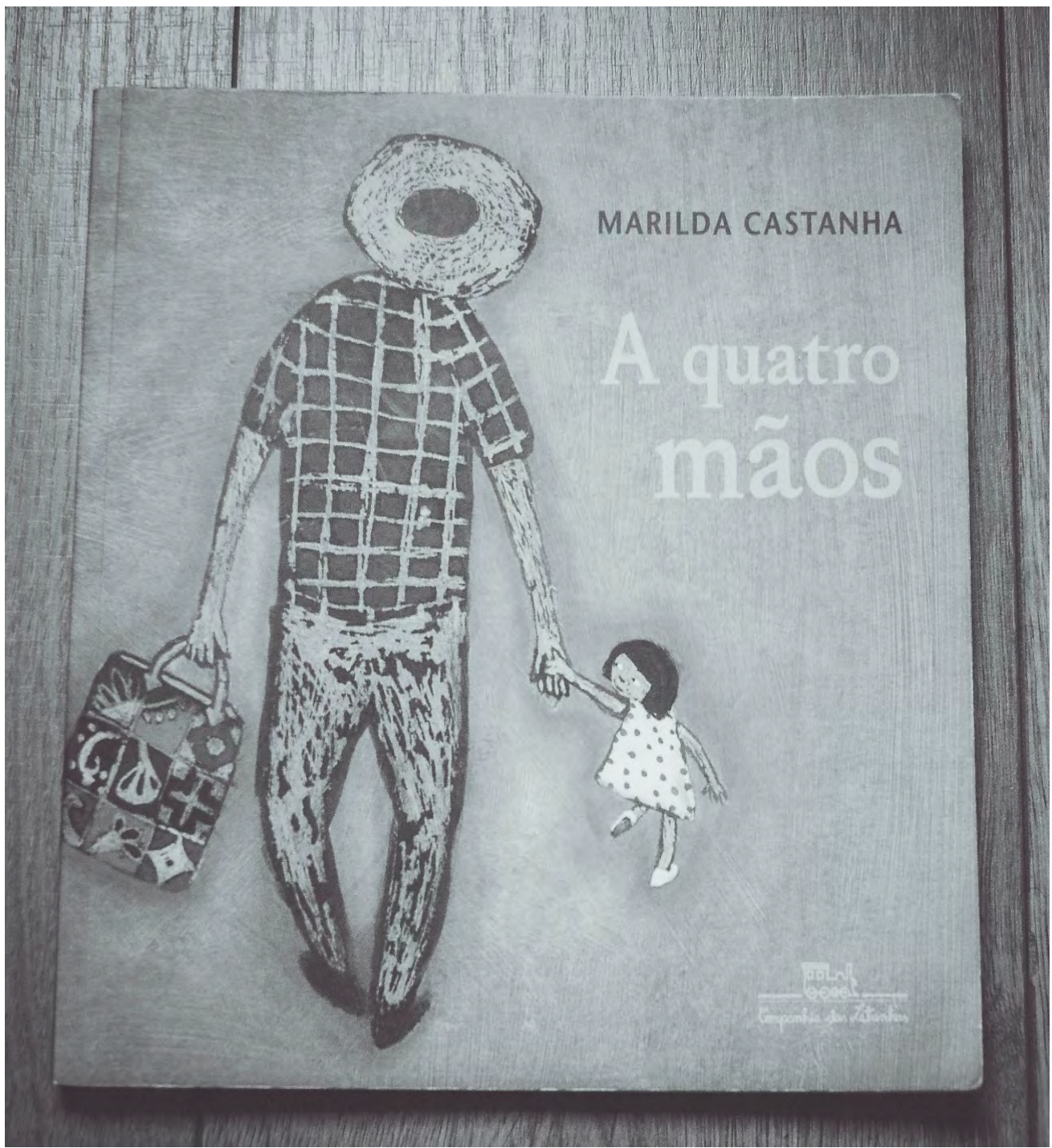

Figura 1 - Capa de A quatro mãos

A quatro mãos (2017), publicado pela Companhia das Letrinhas, foi escrito e ilustrado por Marilda Castanha e pistas 
textuais e depoimentos da escritora-ilustradora nos dizem que se trata de uma homenagem ao seu pai. O livro tematiza a infância de uma menina e sua inserção no universo familiar, demarcada pelo amor e cuidado expressos, principalmente, pelas mãos paternas.

A passagem de tempo em diferentes épocas da vida da menina, como a gravidez da mãe, os primeiros anos de vida e a fase adulta, mostra o natural e inexorável envelhecimento do pai e posteriormente a sua morte. Permeia a obra um jogo linguístico com a palavra mãos, que metaforicamente guia o texto verbal - com expressões como "mãos de ferro", "abrem mão", "deixar na mão" - e imagético, que retrata os detalhes, os gestos e os ensinamentos do pai que proporcionam à criança aprendizado sobre a vida.

Já na capa, sobre fundo marrom, é possível visualizar dois personagens principais da trama, um adulto de mãos dadas com uma criança, e a posição de ambos sugere que estão caminhando, o que é possível constatar ao analisar a contracapa que apresenta alguns postes de iluminação delimitando um caminho a ser percorrido. Na lateral direita encontra-se o nome da autora e o título do livro, que se destaca pelo tamanho diferente da fonte com as letras minúsculas na cor amarela. O livro foi impresso em papel 
alta alvura, com acabamento em brochura, e é composto por 72 páginas em formato quadrado com dimensão de $20,50 \mathrm{~cm}$ por 20,50 . Nas páginas duplas, os recursos gráficos propiciam uma interação entre as ilustrações com cores vibrantes e frases curtas que levam o leitor a percorrer a obra estabelecendo um certo ritmo de leitura. Como afirma Linden "o livro ilustrado mantém estreita relação com a página dupla. Assim, é determinante a forma como textos e imagens se inscrevem nesse espaço" (2011, p.65).

Antes da dedicatória, a autora retrata em página dupla a cena de uma criança de mãos dadas com os possíveis pais. Na página seguinte, apresenta-se a imagem de uma criança olhando para o adulto, acompanhada da dedicatória ao pai. O enredo inicia-se com a imagem de uma casa que ocupa o lado esquerdo da página, e a representação de uma mulher grávida ao lado do marido. É possível evidenciar por meio das cenas que o cenário onde a narrativa se passa é caracterizado pela presença de um ambiente típico de cidade pequenas do interior que foram representados pelo quintal da casa da família, com a presença de animais, da horta, de plantas, entre elas uma jabuticabeira. Nota-se também o surgimento de uma estação de trem, onde a menina e seu pai embarcam para uma viagem que perpassa um cenário 
montanhoso. Todas essas imagens remetem ao interior do estado de Minas Gerais, terra natal da autora.

Nas páginas, estão presentes elementos relacionados à passagem de tempo, como a criança ainda bebê em ações orientadas pelas mãos da mãe. Nessas cenas com a figura materna, observa-se a predominância da cor branca e o ambiente remete ao interior da casa. As páginas seguintes apresentam as interações estabelecidas entre a menina, que vivencia diferentes momentos cotidianos de sua infância com seu pai, ainda jovem. Os cenários que representam essa relação são variados, com elementos também diferentes, com ambientes externos e internos à casa da família, como o expresso na cena que remete à cozinha da residência e que é representada em tons cinza em que os personagens estão à luz de velas.

Ao findar essa relação entre o pai e a filha, tem-se novamente a representação da passagem de tempo expresso nas palavras e nas imagens, na qual vê-se a figura do pai segurando uma cesta com ovos numerados. Os ovos, ao mesmo tempo, podem ser interpretados como a fragilidade da vida. A partir dessa página, percebem-se mudanças nas cores, que deixam de ser vivas e passam a um tom sombrio, representado pelo marrom. Ao virar a folha, 
o leitor se depara com a cena da capa do livro, porém, com os personagens em posições diferentes, acompanhados da frase "mãos guardam numa sacola de mão", e na página seguinte tem-se a representação da sacola como um registro da memória, representado pelos diferentes objetos que emolduram a frase "memórias de uma vida inteira." Há uma nova passagem de tempo, e a menina cresce, a figura paterna não é mais vista. Na cena que se segue tem-se o foco em uma personagem que recobre o rosto com as mãos, o vestido sugere ser a filha. Ao seu lado pessoas caminhando em um funeral. As páginas finais representam recordações e o encontro afetuoso entre um adulto e uma jovem. 


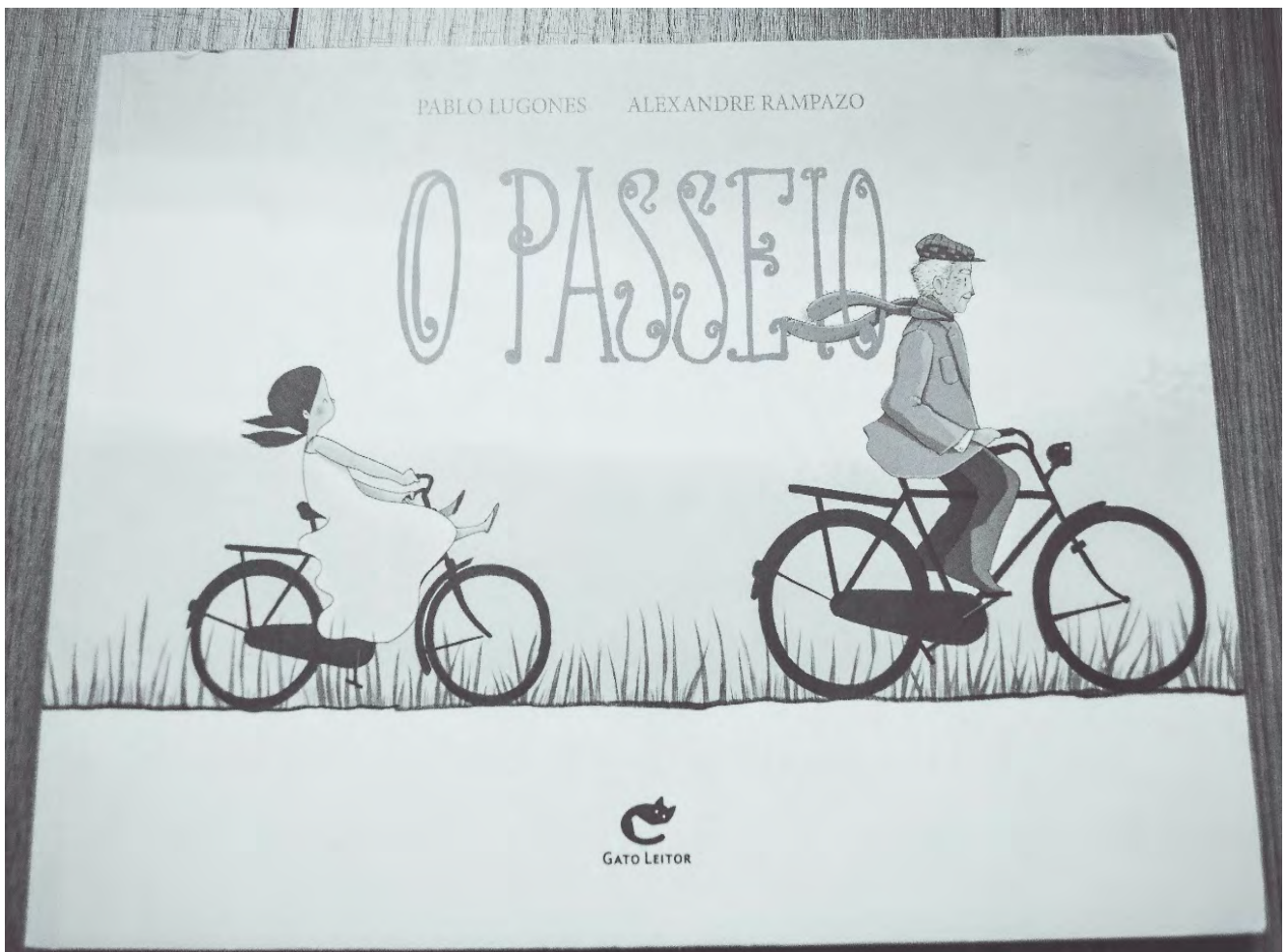

Figura 2 - Capa de $O$ passeio

O segundo livro premiado aqui analisado é O passeio (2017), escrito por Pablo Lugones, com ilustrações de Alexandre Rampazo e editado pela Gato Leitor. A obra apresenta formato retangular horizontal, de $28 \mathrm{~cm}$ por $20 \mathrm{~cm}$, "por ser mais largo que alto, [esse tipo de livro] permite uma organização plana das imagens, favorecendo a expressão do movimento e do tempo, e a realização de imagens sequenciais" (LINDEN, 2011, p.53). A obra apresenta ilustrações que se abrem para muitos significados, dispostas em folhas duplas, o que possibilita 
ao leitor uma visão privilegiada, panorâmica, de cada cena. Com cinquenta e duas páginas, a narrativa tematiza o vínculo afetivo estabelecido entre pai e filha no decorrer do ciclo da vida que é representado pela metáfora do passeio em que os personagens realizam ao andar de bicicleta. É possível ao leitor acompanhar o trajeto dessa relação à maneira de uma linha do tempo, com seus variados ritmos, intensos ou lentos, em posições diversas e carregados de sensações relatadas pela filha que vivencia e narra os fatos.

A capa e quarta capa do livro, com cores em tons claros de azul, que representam o céu, já apresentam ao leitor indicativos acerca do enredo da obra. Nas bicicletas figuram um senhor ao lado direito da capa, seguido por uma criança e, ao centro, entre os personagens, está o título em letras maiúsculas. Tal disposição transmite a ideia de passagem de tempo relativo à idade dos personagens da história. Existe em todas as páginas duplas, assim como na capa e quarta capa, o uso da linha reta como recurso gráfico para indicar o percurso realizado pela bicicleta, o que possibilita estabelecer sentido quanto aos movimentos realizados em aclives, declives, expressando profundidade e continuidade. Esse recurso foi usado também para delimitar o espaço entre as cenas e o texto escrito com tipografia em imprensa 
minúscula de cor preta sobre o fundo branco na parte inferior das páginas. Outro ponto destacado é que a narrativa visual se desenvolve da esquerda para a direita, dando ideia de movimento.

A primeira cena do livro mostra um jovem pai que ensina a filha a andar de bicicleta. Nessas páginas não há texto verbal e a cor predominante do fundo é um tom de azul claro e branco. Na página dupla seguinte, as imagens mostram o pai a observar a filha que narra os fatos. Seguindo a paginação, acrescentam-se na narrativa imagética elementos novos, como a borboleta que salta de uma pequena vegetação e voa em direção à menina. Ao virar a página, na lateral esquerda, observa-se a entrada da roda de uma outra bicicleta, o que produz no leitor a sensação da existência de algo além das extremidades da página, que no jargão editorial é denominado de imagens sangradas. Na décima página, a cena apresenta a bicicleta com a criança à frente, seguida pelo pai em outra bicicleta, tentando alcançar a filha. Nota-se na ilustração que a borboleta está próxima da figura paterna. As sensações de movimento e velocidade são expressas na ilustração pela perda do boné e o esvoaçante cabelo da personagem.

Na sequência, o leitor é surpreendido com alterações nos personagens e no cenário. O pai e a filha estão fisicamente 
mais velhos, as roupas são diferentes das usadas no início da narrativa. Nota-se, no ambiente, o crescimento da vegetação que recobre todo o percurso por onde passa a bicicleta, de uma extremidade a outra da página. No céu observa-se uma mudança no tom da cor azul. O posicionamento em que foram retratados os personagens sugere um distanciamento entre os dois, a menina encontra-se na posição contrária, seguindo atrás do pai, esse último está sempre acompanhado da borboleta. Nas próximas dez páginas seguintes, a passagem de tempo continua e é representada na narrativa pelas alterações dos personagens que alternam posições e emoções durante o passeio, ora distantes, ora próximos, como uma metáfora para a vida. É possível perceber que o uso das cores presentes no fundo modifica-se a cada transformação dos personagens e dos cenários, de tom azul claro ao escuro, auxiliando na compreensão da passagem de tempo. O tom de cor escuro destaca a personagem triste. Nesse sentido, a cor é "um dos elementos constituintes da imagem narrativa que possui o maior poder emotivo e evocativo" (OLIVEIRA, 2008, p.50).

No clímax da história, existem algumas pistas para que o leitor compreenda o que está implícito. O cenário é representado pela chegada da noite com o céu estrelado, a 
vegetação está maior e a filha aparece passeando sozinha em sua bicicleta. Nos próximos pares de páginas não há narrativa verbal, sinalizando o silêncio. O texto escrito é retomado na página subsequente, mas não revela o que aconteceu. $\mathrm{Na}$ sequência, a personagem desce da bicicleta, vira-se para trás e acena. Nota-se no canto esquerdo da página uma luz que reflete no céu. O momento de reflexão da menina termina quando a borboleta se aproxima e passa a acompanhá-la na bicicleta. O cenário apresenta elementos diferentes, a cor do céu modifica-se para um tom claro e a vegetação começa a baixar novamente recobrindo somente uma das páginas. Nas últimas cenas do livro, a narrativa visual e imagética sugere o início de um novo ciclo do passeio, que é representado pela filha a ensinar o seu filho a andar de bicicleta. 


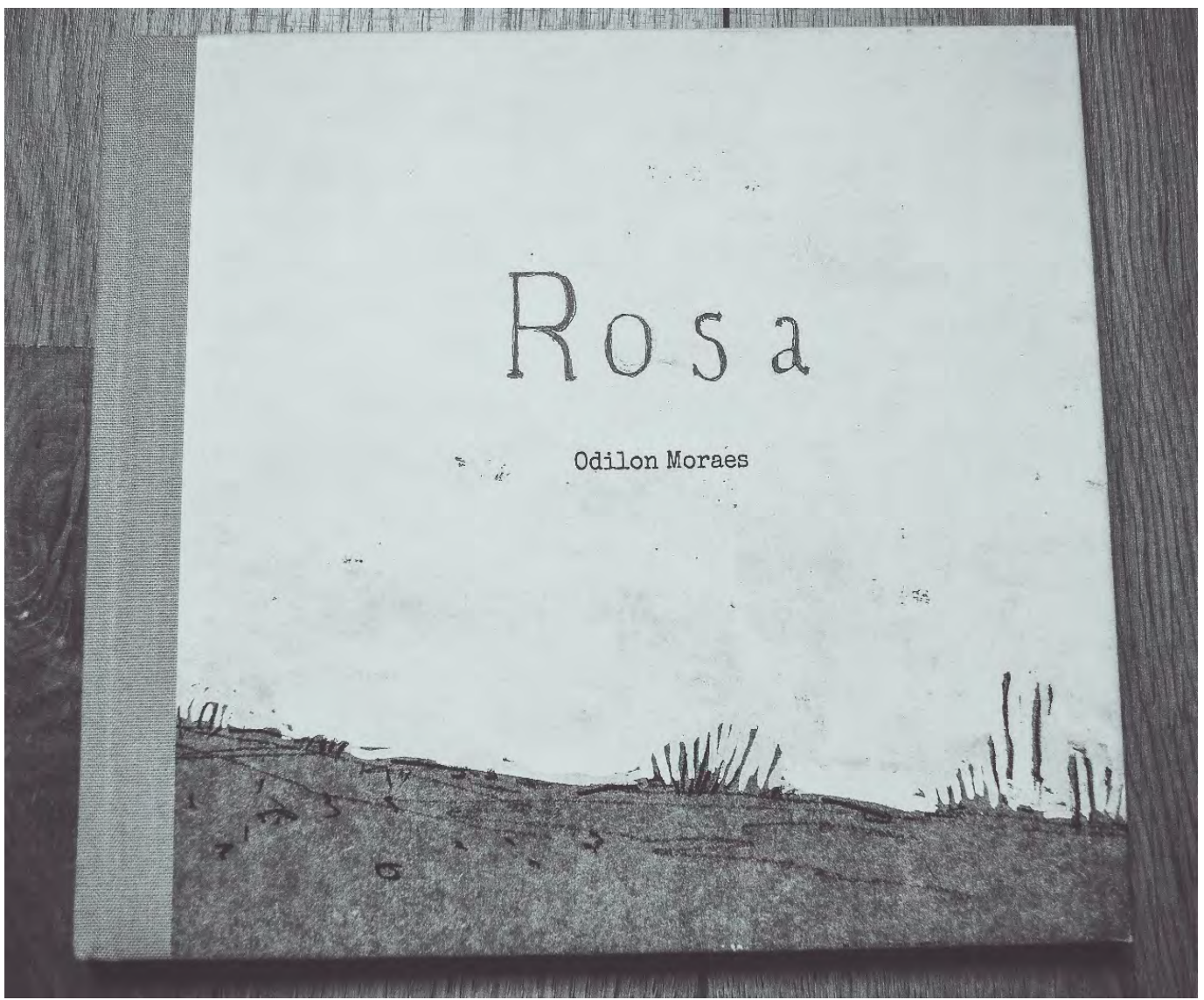

Figura 3 - Capa de Rosa

Rosa (2017), publicado pela editora Olho de vidro é a terceira obra apresentada e analisada. Odilon Moraes é o responsável pelo texto verbal, pelas ilustrações e pelo projeto. O livro foi premiado nas categorias Criança e Melhor Ilustração. O autor, ao vivenciar a paternidade e refletir sobre a sua relação com o seu pai, propôs, nessa obra, um 
diálogo intertextual com o conto emblemático de Guimarães Rosa "A terceira margem do rio." A história é "narrada" com traços fortes e apresenta a relação distante e silenciosa estabelecida pelo pai que nomeia o filho recém-nascido de Rosa (a referência ao autor do conto com o qual o livro dialoga não podia ser mais explícita) e, posteriormente, se isola em uma canoa no meio do rio, sem retornar à família, tal como no conto rosiano: "rio abaixo, rio afora, rio adentro" são palavras que aparecem na narrativa de Odilon Moraes.

O livro é um excelente exemplo das várias possibilidades de leitura de uma obra, posto que as ilustrações presentes em páginas duplas e o texto com frases curtas narram a história em tempos diferenciados, ou seja, o texto verbal e o imagético atuam harmoniosamente para o desenrolar da história, porém, tem-se narrativas diferentes. As ilustrações fazem parte do enredo, mas não aparecem para representar o texto verbal. Pode-se afirmar, portanto, que as imagens ampliam os sentidos do texto verbal, não apenas o repetem ou ilustram. No paratexto da quarta capa, é possível inferir que pelo texto escrito compreende-se a narrativa por uma margem, que conta a história do pai que vai embora em viagem pelo rio. Da outra margem, em outro tempo e pela análise das imagens, conhece-se o percurso realizado 
pelo filho que retorna à casa de sua infância em busca de lembranças do pai. Cabe ao leitor construir sentidos e alcançar a terceira margem. Talvez seja esta sofisticação do livro que tenha afastado um pouco os leitores na prática pedagógica proposta.

No que tange à materialidade do exemplar, a obra apresenta folhas de guarda com predominância do tom marrom. O livro tem formato retangular, medindo $22,05 \mathrm{~cm}$ por $19 \mathrm{~cm}$, com acabamento em capa dura. A lombada é revestida em tecido e as folhas em papel com maior gramatura convidam o leitor a descobrir sensações e garantem ao objeto maior durabilidade, ao mesmo tempo em que também o encarecem. Em algumas cenas, as ilustrações com traços ágeis preenchem as páginas e demandam do leitor uma apreciação mais demorada para fruição. Os traços fortes e a pintura em aquarela com tons de preto, branco leitoso e tons de marrom predominam na maioria das páginas do exemplar.

Com o livro aberto, e o olhar atento na capa e quarta capa, visualiza-se na parte inferior a representação da margem que leva o leitor ao encontro do rio. Uma canoa é retratada na lateral esquerda da quarta capa e não há personagens. O título da obra ocupa posição central, em tipografia de 
imprensa minúscula com nuances das cores vermelha e rosa, acompanhado logo abaixo pelo nome do autor em um fundo branco fosco. Tais elementos não revelam claramente o que se esperar da história. Ao iniciar a leitura temos outra referência ao conto de Guimaraens Rosa, presente na epígrafe: "Pai, o senhor me leva junto, nessa sua canoa?" (MORAES, 2017). A história se abre, e é constituída somente por imagens que retratam um homem segurando uma mala, em uma estação de trem. Ao virar a página, tem-se o personagem em uma carroça indo em busca de sua própria história, enquanto inicia-se a narrativa verbal, em tipografia de impressa minúscula, anunciando o nascimento do filho. Na página seguinte, o texto verbal talvez possa causar um certo estranhamento no leitor, quando o pai escolhe para o filho o nome de uma flor, Rosa. A sequência de páginas seguintes mostra o homem em sua busca solitária pelo pai. Seguindo a paginação, as cores escuras anunciam a chegada da noite, com o filho a entrar na antiga casa.

As próximas páginas duplas apresentam o homem no ambiente interno da casa, as cenas que se seguem retratam a canoa e a sua partida rio adentro, distanciando-se da casa. Observa-se que à medida que a narrativa vai chegando ao final, as cores e as formas modificam-se, passam de cores 
com tons mais claros em páginas quase vazias, simbolizando o silêncio. Ao encerrar a obra, não são oferecidas explicações. A obra deixa em aberto o final, para que cada leitor construa suas próprias interpretações. Na última página, está a dedicatória do autor ao seu pai, que Ihe deu o silêncio e ao seu filho que ocupou esse espaço vazio.

Essas são as possibilidades de leitura que nós, adultos e professores, apresentamos sobre as três obras premiadas na categoria Criança pela FNLIJ em 2018. Na próxima seção, veremos como as crianças receberam as obras, a partir de uma prática pedagógica realizada por uma das autoras deste artigo.

\section{RECEPÇÃO DAS OBRAS NA BIBLIOTECA ESCOLAR: A VOZ DE LEITORES EM FORMAÇÃO}

Um leitor não se forma, um leitor se constrói. A leitura não é um hábito, mas uma habilidade desenvolvida ao longo da infância e que terá reflexos na vida adulta. Leonardo Cazes, O Globo, 10/06/17

Com o intuito de observar e analisar a recepção das crianças dos três livros premiados, optamos pela proposição de uma prática pedagógica com um grupo de alunos do ciclo de alfabetização de uma escola pública municipal de uma cidade do interior mineiro, na região em que se situa a Universidade Federal de Ouro Preto. Para ouvir e dialogar com os pequenos leitores, adotamos como 
estratégia metodológica uma prática próxima ao que se tem chamado de "círculo de leitura", caracterizado como "o compartilhamento organizado de uma obra dentro de uma comunidade de leitores que se constitui para tal fim" (COSSON, 2017, p.158).

O espaço escolhido para a realização da prática foi a biblioteca escolar, onde reunimos os alunos em três grupos de nove crianças, com faixa etária entre sete e oito anos. Nosso intuito em organizar o local era de estabelecer um clima propício para observação dos exemplares, interação e compartilhamento das impressões e significações a partir da leitura e apreciação das obras. Pensar na formação do leitor literário contemporâneo requer pensar espaços, enriquecer as trocas de experiências e a diversidade de interpretações por meio de compartilhamentos. Para gravar as interações que se estabeleceram utilizamos uma câmera fotográfica ministrada por uma funcionária do ambiente escolar. No ato da escolha, os três livros foram expostos sobre uma mesa com as capas viradas para cima para uma melhor visualização, manipulação e seleção de um exemplar por cada grupo.

O percurso investigativo envolveu três etapas. Em um primeiro momento, propusemos a cada grupo a escolha do livro que mais despertou o interesse para a leitura. Nessa fase, 
não foram realizadas mediações a fim de não influenciar nas escolhas e perceber como as crianças liam e interagiam com a obra. Durante o período em que cada grupo separadamente interagiu e apreciou o exemplar, foi possível observar que os leitores conversaram entre si, folhearam e transitaram pelas linguagens visual e verbal e destacaram características importantes do projeto gráfico, fazendo comentários como: "Este livro não tem número de páginas", "este livro aqui não tem muitas palavras, não tem palavras aqui nesta parte", "olhem a luz, olhem bem essa luz".

Posteriormente, em um segundo momento, com a leitura e apreciação do livro escolhido por cada grupo, convidamos todas as crianças para se reunirem em um círculo e compartilhar as impressões relativas às obras premiadas disponibilizadas. Nessa etapa, o interesse era focalizar os argumentos e identificar quais elementos constituintes do objeto livro foram determinantes para a seleção da obra a ser lida por elas. Após os questionamentos, ambos os grupos apontaram como critério decisivo para a escolha elementos presentes na capa como o título e as ilustrações, como é expresso no relato em que a criança justifica sua escolha pelo livro O passeio (2017): “Gostei do título e da capa, porque eles passearam desde quando a menina era criança até ela 
ficar adulta e o pai ficar idoso. Tem a fase que eles começam e a fase que ele termina, ele morre no final".

Ao dialogar sobre a obra A quatro mãos (2017), o pequeno leitor apresentou sua apropriação da narrativa "A história conta sobre as mãos do tempo, que o tempo pode ser cruel e levar muitas pessoas que a gente ama... igual aconteceu nessa página aqui." A pesquisadora estimula o estudante a realizar a exploração da página apontada e ativar mecanismos de interpretação, questionando: "O aconteceu aqui?". Ao responder aponta para a cena “Aqui é o enterro dessa menina que aparece no início do livro. Aqui são os pais, os avós." Com imaginação, reflexão e criatividade os pequenos leitores ampliam as possibilidades de leitura da narrativa.

O grupo que estava com o livro Rosa (2017) apresentou, inicialmente, estranhamento quanto às ilustrações e um dos integrantes destacou: "Minha nossa, que livro rabiscado e essas cores." Demostraram atenção também para aspectos constituintes da materialidade da obra "A capa é dura. Isso é um tecido?". Uma outra criança manifestou seu ponto de vista "Eu achei bonito e bem triste...por causa que...olha, o pai não gostava da filha e a deixou mundo afora." A leitura desse surpreendente livro desafiou os discentes dada a necessidade de compreender as várias linguagens que 
interagem e demandam a leitura conjunta de suas múltiplas camadas para atribuição de sentido, o que provocou, em determinado momento, o desejo do leitores em sanar dúvidas e ler o livro junto com a pesquisadora.

Ao findar as primeiras considerações das crianças em relação à leitura realizada, os exemplares voltaram para o centro da roda e iniciamos o terceiro momento que contemplava uma nova escolha de uma das três obras para uma segunda leitura a ser realizada com a nossa mediação. Nessa fase, os alunos optaram pela leitura compartilhada do livro O passeio (2017). A pesquisadora posicionou-se na roda de forma que fosse possível observar e ouvir todas as crianças presentes no círculo. Essa organização foi relevante para visibilidade do texto literário, para a leitura da narrativa de forma compartilhada e apresentação das impressões entre os presentes. Pesquisadoras do letramento literário, Grossi e Machado destacam: "Essas atividades de leitura compartilhada com a finalidade de observação e escuta requerem do pesquisador uma atitude isenta de julgamentos prévios ou ideias preconcebidas sobre o que os livros oferecem" (2018, p.61).

A nossa mediação se estabeleceu de forma próxima dos discentes durante todo o processo na busca por incentivar 
"manifestações - palavras, gestos, avaliações, comentários - das crianças diante do que leem" (SOARES; PAIVA, 2014, p.13). Assim, tão logo se iniciou a contextualização do exemplar, os olhares de encantamento com o livro já eram expressivos. Ao apresentarmos a capa e a quarta capa, um aluno destacou a disposição dos personagens na página e atentou para um recurso gráfico, a linha horizontal: "Olha! parece que eles já andaram muito de bicicleta." Ao ser indagado sobre a afirmação buscou se basear na posição ocupada pelos personagens representados na capa do livro.

Ao prosseguir com o passar das páginas duplas buscamos incentivar a exploração dos diferentes modos de representação que compõem o objeto livro ilustrado, possibilitando a reflexão sobre elementos da narrativa verbal e imagética, a análise das linhas, formas, cores, personagens dispostos nas páginas, dentre outros aspectos que contribuem com a manifestação das percepções dos pequenos leitores. No episódio transcrito temos um trecho de um dos diálogos estabelecidos:

Pesquisadora: $O$ que percebem nesta página?

Criança 1: Ela virou adulta e o pai está um pouco mais velho.

Criança 2: Essa borboleta eu acho que é a mãe dela, ela está desde o início. 
Pesquisadora: $O$ que mais tem na cena? 0 que acontece com os personagens?

Criança 1: O pai está na frente agora.

Pesquisadora: Por que será isso?

Criança 3: Acho que por causa que é da infância até a melhor idade.

Criança 4: O mato cresceu.

Criança 1: O céu também mudou, era verde água e está meio azul. As roupas também.

Pesquisadora: Em relação a mudança de cor do céu, será que tem um motivo?

Criança 2: Foi o tempo que foi voando.

Criança 5: Eu acho que sei o porquê que o mato tá crescendo, é à medida que ela vai ficando mais velha.

Durante o debate foi possível perceber que o livro desafiou os estudantes, que se mostraram curiosos e encantados frente aos elementos postos. Levantaram várias hipóteses sobre as cenas, requisitaram a atenção um do outro, dialogando sobre detalhes do texto ou das imagens e, dessa forma, foram atribuindo sentidos à história. Em um dado momento, uma menina chama a atenção para a narrativa verbal: "Olha, tem algo escrito aí", e a outra completa: "Ele perguntou sobre o que seria melhor se era continuar em um ritmo acelerado?". Questionamos sobre o significado dessa pergunta, o grupo refletiu sobre a questão colocada e buscou respostas na análise da narrativa imagética, antecipando a 
narrativa verbal e assim concluíram que "Ela quer dizer que se correr muito ela não vai aproveitar o pai dela enquanto ele vive, porque ele já tá velho e vai morrer." As crianças relacionaram também que a personagem fazia referência à passagem do tempo e o decorrer da vida.

A temática abordada, a mudança no cenário com as cores no céu e na roupa dos personagens proposta no livro possibilitaram às crianças estabelecer significações e aproximações com suas vivências: "O céu está ficando escuro, acho que o sol está se pondo e quando ele acabar de se pôr o pai dela vai falecer", "parece que ele sabe que vai falecer, está com roupas de funeral, sabe?", "O céu está escuro porque é cor de velório", "Minha mãe não pode viver isso com o pai dela, ele morreu quando ela tinha sete anos".

Em uma das páginas, com destaque à visualidade da cena em que a personagem refletia, os alunos não identificaram a ausência do texto verbal, até o momento em que problematizamos para ajudá-las a refletir e construir um percurso de análise sobre o que estava sendo posto. Rapidamente uma criança estabeleceu relação com a função da personagem que narrava os fatos e dialogou com a expressão dela retratada na ilustração e respondeu: "É porque ela está triste, o pai dela morreu e ela não quer falar 
nada." Ao chegar nas últimas páginas do livro, apresentaram algumas indagações sobre a personagem e o filho e trouxeram informações sobre o ciclo que iniciava e, tendo como base a linguagem visual, concluíram: "Já sei, vai acontecer tudo novamente". Quando desafiados a explicar o que motivou a afirmação, uma das crianças pediu para voltar ao início do livro e visualizar as primeiras imagens: "Olha o começo do livro, ele começa com essa página e volta aqui no final".

Ao encerrar, uma das crianças não se limitou ao final proposto e criou oralmente sua narrativa da sequência do passeio, protagonizados pela filha e o filho "A mãe vai ensinar as mesmas coisas para o filho, só que vai acontecer uma coisa diferente com o filho. Ele vai andando...andando e a mãe quem vai morrer no final". Percebe-se assim que a obra foi convidativa, fomentou a criatividade e a capacidade de complementação da narrativa.

\section{CONSIDERAÇÕES FINAIS}

Na epígrafe da seção anterior, o jornalista Leonardo Cazes afirma que "um leitor não se forma, um leitor se constrói" no início de uma matéria em que apresenta o livro da ilustradora e jornalista Graça Ramos, intitulado Habitar a infância: como ler literatura infantil (Tema Editorial). Embora apareça logo no início da sua matéria, percebe-se que esta é uma das 
conclusões a que chega o jornalista depois de ler e resenhar o livro da colega. Optamos por usar tal epígrafe na seção que mostra a prática pedagógica que propusemos e analisamos, pois essa prática nos conduz à mesma conclusão. Embora seja corrente o uso da expressão "formação de leitores" e nós mesmos a adotamos em inúmeras ocasiões, acreditamos mesmo na validade da ideia de que um leitor é construído da mesma forma que, décadas atrás, tornou-se praticamente um consenso entre os pesquisadores da leitura, literária ou não, de que o(s) sentido(s) não estão no texto, o(s) sentido(s) são construídos no momento da leitura, e que variam de leitura para leitura, de leitor para leitor, de momento para momento de leitura, de condições como leitura solitária e leitura compartilhada. Mais do que por um “hábito", a leitura literária ideal é aquela realizada pelo desejo.

Os dados coletados a partir da prática pedagógica oferecida às crianças, dos livros ilustrados premiadas pela FNLIJ, possibilitaram-nos evidenciar que alguns elementos desafiaram os "leitores em construção" e que eles transitaram pelas diferentes camadas de signos curiosos e instigados. Os livros, com articulação criativa e eficiente entre as linguagens, fomentaram o interesse dos alunos, o que possibilitou levantar hipóteses, antecipar o conteúdo, chamar a atenção 
um do outro para detalhes do projeto gráfico e construir significações para o texto literário. Verificamos também que as crianças apresentaram em suas falas detalhes relevantes que se abrem para outras possibilidades de leitura.

A prática realizada também nos permite refletir sobre a relevância da mediação de leitura para assegurar às crianças, além do acesso aos livros com qualidade literária, uma leitura da obra observando-se melhor a sua riqueza de detalhes. Nesse sentido, concluímos que as práticas com a leitura de literatura infantil no ambiente escolar devam assegurar métodos apropriados para a exploração e compreensão textual, o que contribuirá para ampliar o repertório de leitura dos leitores em formação, bem como proporcionar uma leitura literária, ultrapassando a simples leitura da literatura e contribuindo para o letramento literário, esse processo contínuo que leva à construção dos leitores. Aos professores e demais mediadores de leitura cabe também oferecer espaço e tempo, no ambiente escolar, para que os leitores possam ter acesso e possam usufruir de obras para eles indicadas. Que o sentido das práticas com a literatura infantil no âmbito escolar possa ser "um processo de compartilhamento, uma competência social. Daí que uma das principais funções da escola seja justamente 
constituir-se como um espaço onde aprendemos a partilhar, a compartilhar, a processar a leitura" (COSSON, 2017, p.36), para que, vida afora, o leitor tenha mais autonomia e base para fazer suas próprias escolhas do texto literário, este importante patrimônio cultural da humanidade.

\section{REFERÊNCIAS}

CORRÊA, Hércules Tolêdo (2016). "Letramento literário na escola". In: Lúcia, Cyranka; Tânia, Magalhães. (Org.). Ensino de linguagem: perspectivas teóricas e práticas pedagógicas. Juiz de Fora: UFJF. CORRÊA, Hércules Tolêdo e MAGALHÃES, Rosângela Márcia (2020). Letramento literário dentro e fora da escola: a recepção de $O$ olho de vidro do meu avô, de Bartolomeu Campos de Queirós, e um projeto de leitura literária realizado com alunos do sexto ano do EF. [Artigo ainda inédito]. COSSON, Rildo (2017). Círculos de leitura e letramento literário. São Paulo: Contexto.

GROSSI, Maria Elisa de Araújo; MACHADO, Maria Zélia Versiani (2018). "A conversação literária com crianças do 1 ำ ciclo de formação humana". In: MACEDO, Maria do Socorro Alencar Nunes (Org.). Educação literária: mediação e prática pedagógica. Recife: Linguaraz.

HUNT, Peter (2010). Crítica, Teoria e Literatura Infantil. Cid Knipel (Trad.). São Paulo: Cosacnaify.

LINDEN, Sophie van der (2011). Para ler o livro ilustrado. São Paulo: Cosac Naify.

LUGONES, Pablo (2017). O passeio. Blumenal: Gato Leitor.

MORAES, Odilon (2017). Rosa. Curitiba: Olho de vidro.

OLIVEIRA, Rui de (2008). Pelos Jardins Boboli: reflexões sobre a arte de ilustrar livros para crianças e jovens. Rio de Janeiro: Nova Fronteira.

PAIVA, Aparecida; SOARES, Magda Becker (2014). "Introdução". In: BRASIL. Ministério da Educação. PNBE na escola: literatura fora da caixa. 
UFMG. In http://portal.mec.gov.br/programa-nacional-biblioteca-daescola/publicacoes?id=20407 Acesso em 10.Jan. 2020.

PAULINO, Graça. COSSON, Rildo (2009). "Letramento Literário: para viver a literatura dentro e fora da escola". In: ZILBERMAN, R.; RÖSING, T. M. K. Escola e leitura: velha crise, novas alternativas. São Paulo: Global, p.61-79. RAMOS, Graça (2011). A imagem nos livros infantis: caminhos para ler o texto visual. Belo Horizonte: Autêntica Editora.

Hércules Tolêdo Corrêa é Doutor em Educação pela UFMG (ou Ph. D.) área Educação e Linguagem. Professor associado da UFOP. Professor da graduação, mestrado e doutorado nas áreas de Educação e Linguagem. Autor de diversos artigos para revistas especializadas, capítulos de livros e livros sobre letramento literário e ensino de literatura. É líder do Grupo de Pesquisa MULTDICS - Multiletramentos e uso das TDIC na Educação. Email: herculest@uol.com.br ORCID iD: https://orcid.org/0000-0001-7368-5635

Daniela de Carvalho Pena Gonçalves é Mestre em Educação pela UFOP. Membro do MULTDIC - Grupo de pesquisa - Multiletramentos e usos de tecnologias digitais de informação e comunicação na Educação / CNPQ. Membro do Núcleo de Estudos e Pesquisa sobre Práticas na Alfabetização e na Inclusão em Educação (NEPPAI/CNPQ).

Email: danielacpena87@gmail.com 